Tinson J., Nancarrow C. \& Brace I. (2008) "Purchase Decision Making and the Increasing Significance of Family Types", Journal of Consumer Marketing Vol. 25, No.1 pp45-56

\title{
Purchase Decision Making and the Increasing Significance of Family Types
}

\author{
Research Paper
}

\author{
Dr Julie Tinson* \\ Lecturer \\ Department of Marketing \\ University of Stirling \\ Stirling \\ FK9 4LA \\ Telephone: 0044786467389 \\ Fax: 0044786464745 \\ Email: j.s.tinson@stir.ac.uk \\ \& \\ Professor Clive Nancarrow \\ Bristol Business School \\ University of the West of England, Bristol \\ Frenchay Campus \\ Coldharbour Lane \\ Bristol \\ BS16 1QY
}

Telephone: 00441173283435

Fax: 00441173282925

Email: clive.nancarrow@uwe.ac.uk

\&

Ian Brace

Director of Research Methods

Taylor Nelson Sofres (TNS)

Westgate

London

W5 1UA

Telephone: 00442089674771

Email: Ian.Brace@tns-global.com 


\title{
Purchase Decision Making and the Increasing Significance of Family Types
}

\begin{abstract}
Purpose The authors note the growing significance of different family types in the West and explore the relationship between the complexity of family relationships typified in single parent, blended and intact families and the involvement of children in purchase decisions. Originality Whilst social trends indicate that the composition of the family will continue to change, little research has been conducted on the impact of changing family structures on consumption behaviour. Methodology The quantitative research is a development based on earlier qualitative research on the three family types and large scale piloting of the questionnaire. Sampling A random sample of mothers with children aged 10-16 were contacted from the TNS Postal Access Panel. Questionnaires were only used where there were responses from both the mother and child. 524 fully completed questionnaires were used for the analysis. Findings The analysis supports the idea that where familial relationships are simpler such as in single parent homes (fewer relationships) then the involvement of the child is greater and in more complex relationships such as in blended homes (where there are step-parents and step children present) a child's involvement may be less marked. Exceptions to the "rule" are discussed as are the theoretical and practical implications.
\end{abstract}

Key Words: Family types, Decision Making, Children, Involvement and Shopping Behaviour 
Dr Julie Tinson is a Lecturer in Marketing at the University of Stirling where she principally teaches Consumer Behaviour and Marketing Communications. Her research interests include family decision making and consumer socialisation. Recent consultancy includes work for Associa (NFU), Barclays Bank, Tpoll and Channel 4.

Professor Clive Nancarrow is Professor of Marketing Research at Bristol Business School, University of the West of England. Research interests include marketing research applications and consumer behaviour. With an academic background in psychology, he pursued a career in market research on both the research agency and client side (L'Oreal) before joining Bristol Business School. He continues to be involved with the marketing research industry in a consultancy role. He has been retained by a number of major international companies and presents regularly at both academic and practitioner conferences.

Ian Brace is Director of Research methods at TNS UK, where his role is to provide consultancy on research methodology and reporting for major projects. TNS is the largest market research company in the world. Ian has been a market researcher for over 30 years, during which time he worked for MAS Survey Research, NOP, Esso Petroleum and BJM Research. He is author or co-author of more than a dozen published papers and has received five industry awards. He is also author of "Questionnaire Design" (2004) and co-author of "An Introduction to market and Social Research" (2006), both published by Kogan Page. 


\section{Introduction}

Family life has changed dramatically in the past three decades in most countries in Europe (Clarke \& Joshi, 2003) and social trends indicate that the composition of the family will continue to change in the West. There has been a decrease in the proportion of households containing an 'intact' family unit (2 biological parents and their dependent children) and an increase in the proportion of lone parents. It is known that 76 per cent of UK children in 2004 lived in a family unit headed by a couple (Social Trends, 2005) although this official data does not differentiate between families headed by couples who are 'intact' or 'blended' (step-parent). Whilst it is acknowledged that 83 per cent of children in step-parent families live with their natural mother, there appears to be little recognition of the difference between 'intact' and 'blended' families. It may be that the difficulty in categorising the 'family' (what the family is and what it means) (BeckGernsheim, 2002) is reflected in these official household statistics.

There have been calls from a variety of social science and business disciplines for research that acknowledges the differing attributes and characteristics of family types to facilitate a better understanding of family life [See for example: Stacey 1998; BeckGernsheim, 2002 and Ekström 2005]. This paper seeks to address previous shortcomings by focusing on the characteristics of family type relative to purchase decision making. This quantitative study explores the extent to which the assumed 'simplicity' of a nuclear (and single parent) family compares with the complexity of a blended or step-parent family across three stages of purchase decision making (information searching, 
discussion and final say) and considers strategies employed by parents to manage the decision making process (and the perception of this approach by their children).

\section{Changes in the Family Unit}

Fragmentation of the family is not a new phenomenon (Cheal, 2002) as blended and single parent families have been commonplace during other periods in history (i.e. wars, the Great Depression etc.). What is unique about the current situation is that there appears to be fewer legal barriers to the increased complexity and it is occurring on a global scale (Maclean \& Eekelaar, 1997). There has been a well-documented decline in the 'intact' or 'traditional' family household (Haskey, 1998) and consequently, step-families (or blended families as described by Brown and Mann, 1990) formed as a result of individuals re-marrying or co-habiting with new partners are more prevalent than single parent households.

It would appear that three distinct family types have emerged: intact, blended (step-parent families) and single parent households. Single parent households will typically, but not exclusively, be headed by females. Blended or step-parent families are the fastest growing type of family in the UK. Mintel (2005) established that as many as 35 per cent of British parents now live as a 'non-traditional' family unit, either because they are single parents (19 per cent) or because they have children from previous relationships (16 per cent) living with them - and around five million British parents have a "nontraditional' family life. 
It has been suggested that 'the greater complexity found in stepfamilies requires redefinitions of...internal boundaries involving rules, roles, alliances and membership within the stepfamily' (Hetherington et al, 1999) and this will undoubtedly involve who makes which decisions within the family. It is likely that decision making for childcentred and family products within blended families is more complex given the additional number of people potentially involved. However, as much of the previous work on blended families and subsequent outcomes has focused on childhood and adolescent development as a result of changing family structure [See for example: Biblarz \& Gottainer, 2000; Rogers \& Rose, 2002; Brown, 2004] the extent to which family type influences consumption behaviour such as decision making and strategies to manage the decision making process is under researched.

\section{Negotiated, Alternating and Multiple Family Types}

We have noted three family types but even within these there are variations. Families regardless of 'type' are complex institutions although studies have shown differences in behaviours and outcomes relative to family type. For example, researchers and clinicians report that step-families, in comparison to non-divorced nuclear families are less cohesive, have less clear expectations and are more flexible in response to change (Bray \& Berger, 1993; Visher \& Visher, 1988). It may be complexity within the family is not simply about the number of people in the family but the types of relationships (i.e. difficult or easy) and the way in which these are managed. 
Further to this, step-family households themselves can be considered 'simple' or 'complex' (Hetherington, 1999). Simple step-families are those in which the children are from the mother's previous marriage only. Complex 'blended' families include siblings within a family having different biological relationships with parents. The situation is compounded by the model or approach adopted when the new step-parent family forms. Thery (1989) posits the 'substitution' model and the 'durability' model when illustrating types of blended family. The first model simply replaces the roles and expectations of the intact nuclear family. That is, possibly to maximise stability for the children of divorce, there is a complete split from (typically) the biological father and the step-father adopts the role of the father. Conversely, the durability model, whilst adding complexity to the roles and boundaries within the new step-family, ensures both biological parents have a role in the new family set-up. It may be that those in a blended family could behave in a similar manner to an intact family with regard to decision making if they have adopted the substitution model.

Interesting to note is that pioneering work conducted in the area of family type indicates that 'blended' families do not think of themselves as unique. Indeed, the growing incidence of step-families has only recently begun to attract much popular or academic interest (Allan \& Crow, 2001) and this may be because there appears to be reluctance even among many step-families to acknowledge that their experiences are likely to be different to those of other family forms. Many prefer to present themselves as just 'ordinary' families (Burgoyne \& Clark, 1984; Ribbens et al, 1996). However, as Hetherington (1999) notes, stabilised step-families have to be together for five years 
before they can be compared with stabilised families in first marriages and as such blended families will be more likely to experience different social and behavioural outcomes in the first five years of co-habitation.

Whilst there is scant literature on single parent families (Ahuja et al., 1998) it is important to note that the measurement of single parent families will become progressively less accurate because of marked changes in unmarried cohabitation and the way in which parent (s) choose to describe their relationships. In addition, extended family arrangements require more attention to the distinction between single-parent families and single-parent households (Bumpass \& Raley, 1995; Nelson, 2006). Recording the details of single parents who also cohabit will have significant consequences for the analysis of data given the additional resources that will be potentially contributed to a co-habiting single parent family compared to that of a single parent household.

\section{Characteristics of Family Type}

\section{Outcome}

It has been noted that relative to their non-divorced peers, adolescents who experience divorce demonstrate more disruptive and aggressive behaviours, more parent-child conflict and less positive parental interaction (Rogers \& Rose, 2002). As a consequence, it may be that relative to the decision making process, blended families will have a greater level of disagreement and are less able to resolve differences. Further to this, Cheal (2002) posits that blended and single parent families are more likely to be reflected in lower socio-economic groups. This indicates that a lack of resource may also 
compound any disagreements or may exacerbate the differences when deciding on childonly or family purchases. It has, however, been observed that compared with married mothers, single mothers shop more often with their children and their children shop alone for the entire family more often compared to children in two parent households (Ahuja et al., 1998). As such single parent families may behave differently during the decision making process although the single parent study (ibid) does not differentiate between married couples (e.g. intact or blended).

\section{Familial Roles and Influence}

Some individuals within the family may have more influence on decision making regardless of family type or gender role preference (i.e. they may make a greater economic contribution to the household, personality type etc.). Children are known to attribute more influence to themselves than do their parents (for example see: Foxman et al, 1989 and Erduran, 1999). Corfman (1987) suggests that this could be a self-serving bias or as a result of social norms (that is the expectation that they will have played a role in decision making even if their role was less than they suggest). Belch et al (1985) and Beatty and Talpade (1994) reported that 'teenage' children (the average age of the children in these studies is 17 years) see themselves as exerting more influence on the family decision process (for example regarding both how much to spend and where to purchase) than do their parents. It is of course possible that whilst the decision may appear to be that of the child, it is set within pre-determined boundaries established by the parents (such as the parent deciding on the model of car and the child choosing the colour) (Tinson \& Nancarrow, 2007). Erduran (1999) suggests that there is a difference 
between making a decision and deciding on a brand. That is, whilst the child may appear to make the final decision, the actual "choice" has been limited by the decisions already made by the parent(s).

Those who are more powerful within the family may use an open approach to foster compliance without ever really having the outcome they favour put at risk. Dempsey (1997) terms this negotiation as a 'token' gesture. A false sense of participation and sharing is promoted which effectively disguises the real basis of power within the relationship. It is important to account for 'hidden influence' in this study.

\section{Research Objectives}

Having noted the limitations of research to-date we explore the characteristics of family type relative to purchase decision making. We examine the extent to which the perceived 'simplicity' of a nuclear (and single parent) family compares with the complexity of a blended or step-parent family across three types of involvement in purchase decision making (information searching, discussion and final say) and consider strategies employed by parents to manage the decision making process (and the perception of this approach by their child).

\section{Method}

The research method is a development based on earlier qualitative research on the three family types and large scale piloting of the questionnaire. 
A random sample of 1,120 mothers with children aged 10-16 were contacted from the TNS Postal Access panel and invited to participate in the study. Quota samples were also used to ensure coverage of households with children in each group was in sufficient numbers (groups: tweenagers; 10-12 year olds, teenagers; 13-14 and 15-16).

An access panel comprises a national (Great Britain) population of adults previously recruited who have expressed a willingness to participate in marketing research projects. 537 mothers accepted the invitation to participate in this project which involved the mother and a specified child in the family each completing a separate questionnaire. Questionnaires were only used if there were responses from both the mother and the child and 13 were rejected because only one of these was received, giving 524 fully completed pairs of questionnaires, a usable response rate of $47 \%$. Envelopes were provided for the child and mother and both were encouraged to complete the questionnaires without conferring and then seal them in the envelopes. Each household received a $£ 5$ shop voucher for completing and returning the two questionnaires. It should be noted we did not interview fathers as previous research has shown a very poor response rate and in addition those that did respond did not seem to be that involved with most purchases. Given this finding, we decided that to insist on the male partner completing and returning the questionnaire would adversely affect response rate and how representative the achieved sample would be. Whilst we would have liked to have compared and contrasted single parent families with single parent households we thought there may be issues regarding the admission that a partner who was earning was co-habiting (e.g. the single 
mother may be in receipt of government subsidies). The concerns related to honesty of responses and non-response.

Comparing the final sample profile to population data the sample was accurate for single parent families versus other family types and within one percentage point accuracy for age of mother (See Table I). However, our sample was 6 percentage points light on $\mathrm{ABC} 1 \mathrm{~s}$ and 6 percentage points higher on C2DEs.

\section{Take in Table I}

The questionnaire probed the following and the findings of these will be presented, in turn, in the following section:

- the characteristics of intact, blended or single parent families in terms of demographics and shopping related behaviour.

- the perceived degree of involvement of the mother and the child in different phases of purchase decisions for casual clothes and a family summer holiday.

- in addition to the above two product categories (casual clothes and a summer holiday) the two family members were asked whether the child had the last say in a wide variety of family purchases and purchases for that child.

- whether there was any perceived disagreement or upset in the decision-making for the two categories examined in detail (casual clothes and a family holiday) and the extent to which this was resolved and how . 


\section{Findings}

We show differences between family types that meet the conventional statistical significance level $(\mathrm{P}<0.05)$ as well as differences approaching this. We regard the study as exploratory and so we are interested in potential differences as we subscribe to the view that data should not be ignored if it is approaching statistical significance (see Brace et al 2004).

To gauge the family type of the respondents, we asked the mother (only) to choose between six statements that best described their family structure. For the purpose of the analysis we then collapsed these six family types into three. This had the greatest impact on the blended family type as four of the six statements referred to possible blended family structures.

The three samples of family types emerged as matched in terms of the gender of the children and their age. However, the three family types do differ in terms of socioeconomic grade composition $(\mathrm{p}<0.01)$. Intact families are skewed upmarket and single parent households skewed down market with blended family types falling in between (See Table II). This concurs with the findings of Cheal (2002).

\section{Take in Table II}




\section{Shopping \& TV Media Profiles}

We now briefly examine differences between family types in terms of the child's shopping behaviour, "disposable income" and TV media habits. Our first question on shopping behaviour comprised a series of statements to determine the frequency of involvement in shopping related activities.

\section{Shopping Antennae (looking around/on the internet)}

Children from intact family households report more often than children from single parent households that they look out for new things in shops (See Table III). This is possibly because intact family parents are more likely to be able to indulge their children given their higher socio-economic profile. Similarly, children from intact family households also report that they look on the internet for information about things they are thinking of buying and like to find out from friends about new things to a greater extent than reported by children from single parent families, again probably reflecting better financial circumstances and access to PCs. Children from blended settings tend to fall between the two.

\section{Take in Table III}

\section{Participation in Shopping Trips (See Table III)}

Interestingly children from single parent families claim to go on shopping trips for their computer games, CDs and DVDs more often than children do from blended and intact families. This supports the findings of Ahuja et al (1998) who indicate that children raised in single parents shop more often with their parent. Examining research we have 
conducted for Channel 4 TV on purchase penetration for these product categories in 2005 suggests socio-economic differences are not an explanation for the differences.

\section{Views Sought by Parents on Purchases for the Parent}

Children from blended homes claim less often they are asked for their advice by parents on things the parents are buying for themselves. This may be because the parents do not want to increase the complexity of the purchase given the potentially greater number of people who could then become involved in the information gathering, discussion and final outcome stage.

\section{Children's Disposable Money}

It is important to note that the following findings on monies given to the child reflect the views of the children only and that there may be incidences where the children overclaim or miscalculate the amount they have been given. The results, however, should be considered indicative of the perceived disposable income of children raised in specific family types.

There is a reasonably strong indication that children raised in intact households more often earn money from part-time/odd jobs than do children from single parent homes $(\mathrm{z}=1.89 ; \mathrm{p}=0.06)$. However, children with single parent mothers are given more "pocket money" than children from intact families $($ Single $=£ 13.94 \mathrm{v}$ Intact $=£ 11.24 \mathrm{p}=<.05)$ with children raised in blended families receiving $£ 12.03$ on average. Children raised in single parent households could be in higher earning activities when they are doing parttime work/odd jobs than is the case with children from intact homes (or may be expected 
to cover more purchases with their money). Equally, children raised in single parent households could be in lower paid part time jobs and just be in receipt of a higher subsidy from the parent. 


\section{TV Media Habits and Attitudes}

There is a difference regarding TV consumption relative to family type. Children from single parent households watch more TV than do children from intact homes $(p<.05)$ with children residing in single parent households watching an average of 3.1 hours per day and children residing in intact households 2.7 hours per day. (Children raised in blended families come somewhere between the other two, watching on average 2.9 hours per day). This could be children from single parent households are left to a greater extent to entertain themselves or because there is less competition regarding choice of TV programme. That is, the child has more opportunity to choose their preferred channel. If this were the case we would expect to see more competition or similar competition in blended family households and while this finding is in the right direction it is not statistically significant. However, this finding could also reflect differences between social groups with children from lower socio economic groups watching more television. This is supported to some extent by internal analysis of the data but is not the total explanation.

\section{The Involvement of Children in Different Phases of the Purchase Decision}

We asked children and their mothers how involved they were in the three phases of purchase decision making for a purchase for the child (casual clothes) and for the family (a family summer holiday). These two product categories were chosen as we were particularly interested in the differences between purchases for the child's sole consumption versus those for the family (as considered by Lee \& Beatty, 2002). (Other 
categories were also considered and are discussed later in the paper). The three phases were:

a) Frequency of looking around in shops, catalogues, internet etc. and

b) Frequency of talking about the options

c) How much say in the final decision

We used four point scales and in the table we show the percentages saying "a lot" and the cumulative of the top two boxes ("A lot/a little" - See Table IV).

\section{Involvement of Children at Each Phase of the Purchase Decision}

The perceptions of the children and mothers regarding the child's involvement seem to correspond very closely (Table IV). Both children and mothers report that there is a higher degree of involvement by children when looking around at choices and having the most say when buying casual clothes than is the case for a family holiday $(\mathrm{p}<.001)$. This concurs with previous research (See: Foxman et al, 1989; Shoham \& Dalakas, 2003) that suggests children are more involved in decision making when the purchase is solely for their personal consumption and contrasts with the findings of Lee \& Beatty (2002) who suggest that adolescents in New Zealand are as involved in the final stage of decision making for family purchases as they are in earlier stages. In addition mothers claim greater child involvement in talking a lot about casual clothes than is the case for summer holidays $(\mathrm{p}<0.01)$. This, however, is not reflected in the reports from the children. This may be because the three stages of decision making (looking, talking and final say) are 
not always identifiable as three separate stages to the children. For example, when buying casual clothes, the three stages of decision making may happen simultaneously (See for example: Beatty \& Talpade, 1994). However, for holidays, the three stages of decision making (looking, talking, final say) may be more distinct.

\section{Take in Table IV}




\section{Analysis by Family Types}

\section{Casual clothes}

Single mothers claim their children look a lot/little round at what is available in terms of casual clothes to a greater extent than other mothers report (See Table V). Children of single mothers to a certain extent endorse this ("look a lot") though in this instance differences are not statistically significant. The explanation for the reported greater involvement may be because the child is expected/wants to be more involved and/or because the single mother more often expects her child to be engaged as there is no-one else to be involved. This also supports the previous findings of Ahuja et al. (1998).

There are also some strong indications that mothers from intact families report their children as being less often involved in talking about the purchase of casual clothes than children from other types of families. This may be because the older profile of mothers in intact households in this study may mean they have particular views with regard to clothing or being generally financially better off the mothers may have some degree of complacency. That is, a bad choice can be "remedied" by another purchase.

\section{Family holiday}

When it comes to family holidays there are clear signs of more involvement by children raised in single parent households and less involvement from children residing in an intact family structure in terms looking around, talking and having a say (See Table V). The findings regarding children raised in blended families show a mixed picture: 
- Children raised in blended families are more involved in looking around than children raised in intact households according to mothers - perhaps a token involvement that is more manageable than involvement in the final decision

- Children raised in blended families are less often involved in having a say than children with single mothers probably because there are others to consider which complicates the management of decision making

Children and mothers from single households agree that the children talk a lot more about the best place to go for a holiday than children in other families. This could be because there are fewer people involved in the decision making process, the single mum is relying on the child to a greater extent (no-one else available), because it is perhaps more important to 'get it right' (possibly fewer resources/opportunities) or there is the possibility of a holiday with an absent father. This is true also of having a final say. However, the picture is complicated by the fact that mothers living in blended households report greater child involvement in terms of talking over options than mothers from intact homes. One might expect blended families to be more complicated than intact families and so to seek simplification and not encourage involvement. On the other hand, there may be a desire to use a 'token' gesture as described by Dempsey (1997) or it may simply reflect as in the case with single mothers the need to consider an absent father and a holiday or contact time with him.

\section{Take in Table $\mathbf{V}$}




\section{Other Product Categories}

Whilst it was possible to examine the three phases of choosing casual clothes and a summer holiday, we wished to examine the degree of involvement in a variety of other product categories for the child and for the family and the length of questionnaire for children in particular meant we needed to simplify the question. We presented children and mothers with a list of product categories and they just had to tick those where the child in question had the final say.

In terms of family purchases (computers for family use, a family car and various family outings for instance) mothers and children from different family settings reported generally low incidence of having a final say though children's reports were higher (in relation to involvement) than those of their mothers and this supports the findings of Foxman et al. (1989) and Erduran (1999). There were no differences between family types.

However, in terms of purchases for the child, mothers from blended households claimed to allow their children to have the final say on sweets, drinks and comics/books to a greater extent than is the case for single mothers. Is this the blended mother making an easy concession either out of feelings of guilt and/or the greater complexity of a blended household meaning it is easier to devolve some decision-making - particularly where personal tastes are involved? Children's reports did not mirror the above differences, however. We need to bear in mind that when considering perceptions of two family members there are a number of possible explanations. This has been described as a 
Distortion of Interpersonal Perception (DIP) reported in (XXX). The DIP phenomenon includes posturing (inflating one's own importance), subtle persuasion (influencing the child without the child being aware of this - akin to 'hidden influence'), out of the loop (not being aware of all the interactions of family members), known preferences (using experience to take other views into consideration without discussion) and all of these may partly explain the different perceptions of each others' involvement in family decision making.

\section{Disagreements, Upset and Resolution}

For casual clothes three quarters of children (76\%) and mums (79\%) report some degree or disagreement over the choice of what to buy. However, nearly all report the disagreement is resolved (92\% of children and $96 \%$ of mothers). The level of disagreement is less when choosing a family holiday $(59 \%$ of children and $54 \%$ of mothers) and again nearly always resolved (96\% of children and $97 \%$ of mothers).

From the child's perspective we found only one significant difference between family types in terms of degree of disagreement and its resolution and this was in the case of a family holiday where both children residing in single parent households and children raised in intact families reported "all disagreement" being sorted out to a greater degree than children in blended families $(\mathrm{p}<.05)$. It is possible that accord is generally more difficult to achieve in a blended setting for a family decision and discord may in some instances have to be tolerated. 
Given the initial high levels of disagreement and then the high degree of successful resolution it is of interest to establish how these disagreements are resolved, namely the strategies employed.

\section{How Potential Disagreements are Managed}

We show the strategies employed by mothers and children in the order of the frequency of their mention by the child (See Table VI).

The findings illustrate when purchasing casual clothes there is a similar level of reporting of mothers siding with the child (statement a). Children do not seem to acknowledge the narrowing down of options by the parent(s) to the same extent as reported by their mothers (statement b). This is perhaps unsurprising as this may well be executed in such a subtle way that the child is simply unaware of the tactic (see XXX DIP phenomenon) or may be that the choice is narrowed down to such an extent that the child feels all choice has been taken away - the choice they really wanted having been excluded - and therefore would consider there to be no 'choice'.

Likewise mothers report a very democratic process of consensus-seeking to a much greater extent than their children (statement d). Mothers were also more likely than children to report that they listened to their child's point of view but then made the final decision (c). Children and mothers broadly agreed on the degree of bartering with emotions or something in exchange which was relatively infrequent ( $\mathrm{f}$ and g). However, mothers report the logical reasoning argument to be more successful to a greater extent 
than children and on the other hand children report tantrums working "mostly" to a greater degree than mothers.

\section{Take in Table VI}

In terms of children's perceptions, those raised in single households thought themselves to be more involved discussing all the options for casual clothes until they can all agree. In terms of mothers, however, this finding is not reflected in such an obvious way (See Table VII). The single child possibly believes s/he is more involved in this way (may generalise from other situations in the household - a 'halo' effect). The blended mother reports the democratic route slightly less often and this may be compensating for the number of children to be managed and as a way of externalising the boundaries within the family.

Given the leaning to the more democratic route it is no surprise to see single mothers are less likely than other mothers to report narrowing down the options and this was mirrored to some extent by their children. Single mothers also admit more often that they are likely to succumb to pleas whilst mothers in blended families are least likely to succumb. Perhaps single mothers are managing fewer emotional situations whilst blended mothers have to manage a more complicated family life and so can not afford to set plea precedence. 
Children raised in intact households claim if they do something in exchange the parents are more likely to give in. However, this difference is not supported by the reports from mothers. The mothers from intact family households may not want others to think that their children have to 'work' for what they 'need' or perhaps know that the exchange often just does not materialise.

\section{Take in Table VII}

\section{Family Summer Holiday}

We used a simpler question to determine how disagreements were resolved for a summer holiday than we used for casual clothes. The reason for this is that those completing the questionnaire may not go on holiday very often whilst shopping for casual clothes is more likely to be a regular event. So for casual clothes we used a frequency scale but for the holiday we simply asked which of the following strategies applied. The reason for this was that frequency measures for summer holidays would inevitably cover several years with problems of memory featuring (telescoping the period and omissions) and of course children would be talking about periods when they were in younger age groups.

Children raised in single parent households and their mothers agree that they discuss all the options until they can agree on one (See Table VIII). The base numbers in Table VIII are derived from the number of respondents who claimed there was some sort of disagreement. Children raised in intact families think this is the case for them too - but their mothers do not as they report whilst they include the children in final discussion they still make the final decision. Mothers residing in blended families and their children 
agree that whilst they listen to the child, the parents make the final decision which may be easier to manage in the more complex setting.

\section{Take in Table VIII}

\section{Summary}

In this study, we compare and contrast three types of families. It should of course be noted that blended families in particular come in a wide variety of assortments and can vary in terms of complexity in structure (Hetherington, 1999). Sample sizes, however, did not permit an examination of these variants within the blended category.

When we examine the reports of mothers and children we observe considerable accord in the total sample but not always in the analysis of differences between family types. This may be as a result of sampling error given the smaller bases or, as we have found in past research, there are other reasons such as mothers influencing or anticipating the child's choice without the child being aware of the subtle influence or simply some respondents inflating or misreading their own importance. In formulating the conclusions below, we look for clues from both the mothers and children and because of the DIP phenomena we do not seek absolute correspondence in the reports from mothers and children. The intention is to examine the simplicity-complexity hypothesis posited in the introduction of this study and consider other factors that may also need to be taken into account.

Overall, there is support for the hypothesis that a child's involvement in purchase decisions is a function of the complexity of familial relationships and so a function of 
family type. For example, children living with single mothers (often the simplest relationship) were more involved in shopping trips for some goods and more often involved in talking about the purchase of the two product categories we studied in more detail (summer holidays and casual clothes). Children and mothers in single parent households also both report greater involvement in others phases of the purchase decision (looking at options and having a say for summer holidays) and in the case of casual clothes mothers of such households report a greater involvement of the children in looking at options.

At the other extreme of complexity, as we thought likely, children in blended households report less often that they are as involved in shopping trips for entertainment products and that their views on purchases the parents intended to make for themselves are less frequently sought. However, mothers living in blended families, perversely for the complexity hypothesis, report a similar level of involvement as single parent households for their children talking about the holiday options - involvement greater than mothers report in intact families (where familial relationships might on average be considered more straightforward.). It is possible that the greater involvement of children in blended homes for a family holiday is born of necessity. In many cases the blended unit may need to consider alternative holiday arrangements with the former partner.

\section{Recommendations for Future Research}

This study, despite being quantitative, was exploratory in nature and raises a number of new hypotheses as to what lies behind the differences we have noted. Ideally we would 
have covered such issues in the questionnaire but the length of the questionnaires would have exceeded the patience of the respondents. Additionally qualitative research, either interviews or ethnographic observation, may have a role to play in teasing out the underlying conditions and motivations that explain differences we have observed between family types. Considering a greater variety of product categories and examining variants of blended family settings (i.e. simple or complex as described by Thery, 1989) and perhaps types of family relationships will allow academics to develop these concepts further, contributing to a deeper understanding of family consumption behaviour.

\section{Managerial Implications and Applications}

For marketers there are clear indications that children in single parent households have greater influence in the choice of the large item, the holiday, than do children from either blended or intact families. Whether or not this is extended to other categories of similar relatively high value family-related items may be something that marketers in these categories may wish to explore.

Also there is possibly a greater need for bonding within the blended unit and a successful holiday is the perfect setting for this as long as everyone can agree on the venue etc. in the first instance. It may also be a reflection of the greater propensity in blended homes to indulge children on occasions given their sometimes potentially more difficult circumstances. The "indulging of children by mothers in blended households" hypothesis is supported by mothers in blended settings reporting more often that their children are permitted to have the final say on sweets, drinks and comics/books. Of course, it could 
also be that life is so complex that devolving some decision-making is a way of dealing with this. Marketers and researchers will be interested in the role of the mother and child in different family types in relation to decision making particularly for child-centered products.

If there is a disagreement in the purchase process then again there was some support for the simplicity-complexity hypothesis with children from single parent households reporting to a greater degree the discussion of casual clothes options until all agree on the choice whilst blended mothers reported this less often. Children and mothers from blended homes reported more often than their single parent counterparts that options were first narrowed down then the child chose from these - a case of simplifying the process and possibly removing contentious options from the decision arena. This knowledge may be useful for developing direct marketing campaigns and for the development of creative work (advertising) relative to family purchases.

Interestingly, mothers from blended homes also reported less often that a child's pleas were successful and given the greater complexity of familial relationships it is not surprising that this is not something to be encouraged. Indeed, they may not want to set a bad precedent amongst the other children in the family. With summer holidays there was partial support for the simplicity-complexity hypothesis as described above though children from intact homes report as often as children from single parent homes the discussion of options until all can agree on one. Of course, the simplicity-complexity hypothesis may not only relate to family type but to the types of relationships within the 
family (Hetherington et al, 1999) and the difficulty or ease with which these are managed.

The study also pointed to other interesting characteristics of the three family types which in part might provide an explanation for some of the differences we report in terms of a child's involvement in purchase decision making (namely the extent of looking around at options, talking about these and having a say in the final decision). Most notably whilst $56 \%$ of intact households are $\mathrm{ABC} 1$ (upper socio-economic), only $35 \%$ of blended and $27 \%$ of single parent homes are so categorised. Marketers and researchers may be interested in this greater wealth and the associated social aspirations and these statistics may explain why children in these households claim to be on the look out for new products to a greater extent and use the internet for more information as their parents may be more prepared and more able to indulge their consumerism to a greater extent. It also may partly explain media consumption differences though this deserves further investigation on a larger sample size where family type could be analysed within socioeconomic groups. Database may allow single parent families to be identified and different strategies adopted for different family types when database marketing in these categories.

The identification of the differences in behaviours between the three family types suggests that there is an opportunity here for researchers to use them as an analysis tool to determine how the different types of family behave differently in other areas. Media consumption, for example, has been shown here to differ between the family groups, but 
more work is required to fully understand and quantify those differences and their implications for media owners. 


\section{References}

Ahuja, R.D., Capella L.M. and Taylor R.D. (1998) "Child influences, attitudinal and behavioural comparisons between single parent and dual parent households in grocery shopping decisions", Journal of Marketing Theory and Practice, Winter, pp.48-62

Allan G. \& Crow G. (2001) Families, Households and Society, Palgrave MacMillan, Basingstoke

Beatty S.E. and Talpade S. (1994) "Adolescent Influence in Family Decision Making: A Replication with Extension”, Journal of Consumer Research, Vol 21, pp.332-341

Beck-Gernsheim E. (2002) Re-inventing the Family: In Search of New Lifestyles, The New Confusion about the Family, Munich, Policy Press, pp1-15

Belch G.E., Belch M.A. and Ceresino G (1985) "Parental and Teenage Child Influences", Journal of Business Research, Vol 13, pp.163-176

Biblarz T.J. \& Gottainer G. (2000) "Family Structure and Children's Success: A Comparison of Widowed and Divorced Single-Mother Families", Journal of Marriage and Family, Vol 62, pp533-548

Brace, I., Nancarrow, C. \& Tinson, J. S. (2004) "Breaking the Rules: Greater Insight and Greater Value?" The Market Research Society Conference London

Bray J.H. \& Berger S.H. (1993) "Development issues in stepfamilies research: Family relationships and parent-child interactions", Journal of Family Psychology, Vol 7, pp.7690

Brown, J.E. and Mann, L. (1990) "The relationship between family structure and process variables and adolescent decision making", Journal of Adolescence, Vol 13, pp.25-37

Brown S. (2004) "Family Structure and Child Well-Being: The Significance of Parental Cohabitation", Journal of Marriage and Family, Vol 66, pp.351-367

Bumpass L \& Raley K. (1995) "Redefining Single-Parent Families: Cohabitation and Changing Family Reality”, Demography, Vol 32, No 1, pp.97-109

Burgoyne J. \& Clark D. (1984) Making a Go of It, Routledge, London

Cheal D. (2002) Sociology of Family Life, Palgrave MacMillan, Basingstoke

Clarke L. \& Joshi H. (2005) "Children's changing families and family resources" in Jenson A.M. \& McKee L. (eds) Children and the Changing Family: Between Transformatio and Negotiation, RoutledgeFalmer, Abingdon pp 15- 26 
Corfman K.P. and Lehmann D.R. (1987) "Models of co-operative decision making and relative influence: an experimental influence of family purchase decisions", Journal of Consumer Research, Vol. 14, pp.1-13

Dempsey K. (1997) Inequalities in Marriage: Australia and Beyond, Oxford University Press, Melbourne

Ekström, K. M. (2005) "Rethinking family consumption-tracking new research perspectives", Advances in Consumer Research, Vol 32, pp.493-497.

Erduran, Y. (1999) "Children are Important Consumers. A Case Study From a Developing Country: Turkey", European Society for Opinion and Marketing Research Conference Proceedings

Foxman, E.R., Tansuhaj, P.S. and Ekstrom, K.M (1989) "Family Members' Perception of Adolescents' Influence in Family Decision Making", Journal of Consumer Research, Vol 15, No 4, pp.482-492

Furstenberg F. (1990) "Divorce and the American Family", Annual Review of Sociology, Vol 16, pp.379-403

Haskey J. 1998 The fragmenting family: does it matter? Institute of Economic Affairs, Health \& Welfare Unit, London

Hetherington E.M., Henderson S.H. \& Reiss D. (1999) (Eds) "Adolescent siblings in stepfamilies: Family functioning and adolescent adjustment", Monographs of the Society for Research in Child Development, Vol 64, pp.1-25

Hetherington E.M. (1999) "Family functioning and the adjustment of adolescent siblings in diverse types of families" in E.M. Hetherington, S.H. Henderson \& D. Reiss (Eds) Adolescent siblings in stepfamilies: Family functioning and adolescent adjustment. Monographs of the Society for Research in Child Development, Vol 64, pp.1-25

Hetherington E.M, W. Clingempeel W.G., Anderson E.R., Deal J.E., Hagan M.S., Hollier E.A., Lindner M.S., MacCoby E.E., Cavanaugh Brown J., O'Connor T.G., Eisenberg M., Rice A.M. and Bennion L.D. (1992) "Coping with Marital Transitions: A Family Systems Perspective" (1992) Monographs of the Society for Research in Child Development, Vol 57, No 2/3, pp.1-238

Lee, K.C.C. and Beatty, S.E. (2002) "Family structure and influence in family decision making", Journal of Consumer Marketing, Vol 19, No 1, pp.24-41

Maclean M. \& Eekelaar J. (1997) The Parental Obligation: A Study of Parenthood Across Households, Hart Publishing, Oxford

Mintel (2005) Marketing to Families, July, Mintel International Group Ltd, London 
Nelson, M. (2006) “Single Mothers 'Do' Family”, Journal of Marriage and Family, Vol 68, No 4, pp.781-795

Ribbens J., Edwards R. \& Gillies, V. (1996) "Parenting and Step-parenting After Divorce/Separation: Issues and Negotiations", Changing Britain, ESRC, 5, pp4-6

Rogers K.B. \& Rose H.A. (2002) "Risk and Resiliency Factors Among Adolescents Who Experience Marital Transitions”, Journal of Marriage and Family, Vol 64, pp.1024-1037

Shoham A. and Dalakas V. (2003) "Family Consumer Decision Making in Israel: the role of teens and parents", Journal of Consumer Marketing, Vol 20, No 3 pp.238-251

Social Trends, UK Office of National Statistics 2005, 35, NSO, London

Social Trends, UK Office of National Statistics 2006, 36, NSO, London

Stacey J. (1998) Brave New Families University of California 2nd Edition, Berkeley

Thery I. (1989) "The Interest of the Child" and the Regulation of the Post-Divorce Family" in C.Smart and S. Sevenhuijsen (eds) Child Custody and the Politics of Gender, Routledge, London pp.78-99

Tinson J. \& Nancarrow C. (2007) "GROwing Up: Tweenagers Involvement in Family Decision Making”, Journal of Consumer Marketing, Vol. 24, No.3, pp.160-170

Visher E.B. \& Visher J.S. (1988) Old Loyalties, New Ties: Therapeutic Strategies and Stepfamilies, Psychology Press, London

Table I Sample Profile (Mothers with children aged 10-16)

\begin{tabular}{|l|c|}
\hline & Sample Profile (n=524) \\
\hline Socio-economic grade & $\%$ \\
\hline AB & 19 \\
\hline C1 & 28 \\
\hline C2 & 23 \\
\hline DE & 31 \\
\hline Single or with a partner & \\
\hline Single & 23 \\
\hline Not single & 77 \\
\hline Age & \\
\hline $15 / 16-45$ & 76 \\
\hline $45+$ & 24 \\
\hline Not stated & 1 \\
\hline
\end{tabular}


Table II Family Type and Socio-Economic Grade

\begin{tabular}{|l|c|c|c|c|}
\hline$\%$ & Total & Single & Blended & Intact \\
\hline & $\mathbf{5 2 4}$ & $\mathbf{1 2 0}$ & $\mathbf{8 3}$ & $\mathbf{3 1 6}$ \\
\hline $\mathrm{AB}$ & 19 & 9 & 11 & 25 \\
\hline $\mathrm{C} 1$ & 28 & 18 & 24 & 31 \\
\hline $\mathrm{C} 2$ & 23 & 21 & 27 & 23 \\
\hline $\mathrm{D}$ & 18 & 21 & 22 & 16 \\
\hline $\mathrm{E}$ & 13 & 32 & 17 & 5 \\
\hline
\end{tabular}


Table III Family Type and Frequency of Shopping Behaviour Reported by Child

\begin{tabular}{|c|c|c|c|c|c|}
\hline & Total & $\begin{array}{l}\text { Single } \\
(S)\end{array}$ & $\begin{array}{l}\text { Blended } \\
(B)\end{array}$ & $\begin{array}{c}\text { Intact } \\
\text { (I) }\end{array}$ & $\begin{array}{c}\text { Statistical } \\
\text { Significance }\end{array}$ \\
\hline \multirow[t]{2}{*}{ Children $n=$} & 524 & 120 & 83 & 316 & \\
\hline & $\%$ & $\%$ & $\%$ & $\%$ & \\
\hline \multicolumn{6}{|l|}{ Look out for new things in shops } \\
\hline All the timelevery time + very often & 64 & 57 & 63 & 68 & $\begin{array}{l}S v I \\
P<0.05\end{array}$ \\
\hline \multicolumn{6}{|l|}{$\begin{array}{l}\text { Look on internet for things I am } \\
\text { thinking of buying }\end{array}$} \\
\hline All the timelevery time + very often & 35 & 27 & 31 & 38 & $\begin{array}{l}S v I \\
P<0.05\end{array}$ \\
\hline \multicolumn{6}{|l|}{$\begin{array}{l}\text { Like to find out from friends about } \\
\text { new things }\end{array}$} \\
\hline All the timelevery time + very often & 53 & 43 & 50 & 56 & $\begin{array}{l}S v I=2.42 \\
p<0.05\end{array}$ \\
\hline \multicolumn{6}{|l|}{$\begin{array}{l}\text { I go on shopping trips for computer } \\
\text { games, CDs and DVDs }\end{array}$} \\
\hline All the timelevery time + very often & 41 & 51 & 38 & 39 & $\begin{array}{l}S v I \\
p<0.05 \\
S v B= \\
P=0.07\end{array}$ \\
\hline \multicolumn{6}{|l|}{$\begin{array}{l}\text { My parents ask me for advice on } \\
\text { products they are buying for } \\
\text { themselves }\end{array}$} \\
\hline All the timelevery time + very often & 22 & 23 & 14 & 24 & $\begin{array}{l}B v I \\
p=0.05 \\
B v S \\
P=0.11\end{array}$ \\
\hline
\end{tabular}


Table IV Involvement of Children at Each Phase of the Purchase Decision

\begin{tabular}{|l|c|c|l|c|c|}
\hline $\begin{array}{c}\text { CASUAL } \\
\text { CLOTHES }\end{array}$ & $\begin{array}{c}\text { Child's } \\
\text { view }\end{array}$ & $\begin{array}{c}\text { Mum's } \\
\text { view }\end{array}$ & $\begin{array}{c}\text { FAMILY } \\
\text { HOLIDAY }\end{array}$ & $\begin{array}{c}\text { Child's } \\
\text { view }\end{array}$ & $\begin{array}{c}\text { Mum's } \\
\text { view }\end{array}$ \\
\hline & $\mathbf{5 2 4}$ & $\mathbf{5 2 4}$ & & $\mathbf{5 2 4}$ & $\mathbf{5 2 4}$ \\
\hline $\begin{array}{l}\text { Look } \\
\text { around }\end{array}$ & $\%$ & $\%$ & & $\%$ & $\%$ \\
\hline A lot & $\mathbf{5 2}$ & 49 & A lot & 16 & 15 \\
\hline A lot/little & $\mathbf{8 4}$ & $\mathbf{8 2}$ & A lot/little & 53 & 47 \\
\hline Talk & & & Talk & & \\
\hline A lot & 39 & 48 & A lot & 39 & 40 \\
\hline A lot/little & $\mathbf{7 5}$ & 83 & A lot/little & 77 & 80 \\
\hline $\begin{array}{l}\text { How much } \\
\text { say }\end{array}$ & & & $\begin{array}{l}\text { How much } \\
\text { say }\end{array}$ & & \\
\hline Most say & 52 & 53 & Most say & 6 & 4 \\
\hline Most/some & $\mathbf{8 7}$ & $\mathbf{9 1}$ & Most/some & 55 & 60 \\
\hline
\end{tabular}

* shaded in table $=$ greater involvement 
Table V Family Type and Involvement in the Purchase Process

\begin{tabular}{|c|c|c|c|c|c|c|c|c|}
\hline $\begin{array}{l}\text { View of the } \\
\text {... }\end{array}$ & ...Child & & & ...Mum & & & $\begin{array}{c}\text { Significance } \\
\text { children }\end{array}$ & $\begin{array}{c}\text { Significance } \\
\text { mothers }\end{array}$ \\
\hline & Single & Blended & Intact & Single & Blended & Intact & & \\
\hline $\begin{array}{l}\text { CASUAL } \\
\text { CLOTHES }\end{array}$ & $\begin{array}{c}\mathrm{n}=120 \\
\%\end{array}$ & $\begin{array}{c}\mathrm{n}=83 \\
\%\end{array}$ & $\begin{array}{c}\mathrm{n}=316 \\
\%\end{array}$ & $\begin{array}{c}\mathrm{n}=120 \\
\%\end{array}$ & $\begin{array}{c}\mathrm{N}=83 \\
\%\end{array}$ & $\begin{array}{c}\mathrm{n}=316 \\
\%\end{array}$ & & \\
\hline \multicolumn{9}{|l|}{ Look round } \\
\hline A lot & 58 & 48 & 50 & 53 & 54 & 47 & - & - \\
\hline A lot/ little & 85 & 77 & 85 & 89 & 81 & 81 & - & $\begin{array}{l}\text { SvI } p<0.05 \\
\text { SvB } p=0.11\end{array}$ \\
\hline \multicolumn{9}{|l|}{ Talk } \\
\hline A lot & 42 & 41 & 37 & 53 & 54 & 45 & - & $\begin{array}{ll}\text { IvB } & p<.014 \\
\text { IvS } & p<0.03\end{array}$ \\
\hline A lot/ little & 79 & 71 & 75 & 85 & 84 & 82 & - & \\
\hline \multicolumn{9}{|l|}{ Much say } \\
\hline Most say & 53 & 52 & 53 & 55 & 47 & 55 & - & - \\
\hline Most/ some & 88 & 88 & 88 & 93 & 88 & 93 & - & - \\
\hline \multicolumn{9}{|l|}{ HOLIDAY } \\
\hline \multicolumn{9}{|l|}{ Look round } \\
\hline A lot & 23 & 16 & 14 & 23 & 22 & 11 & SvI $p<0.05$ & $\begin{array}{l}\text { SvI } p<0.01 \\
\text { BvI } p<0.01\end{array}$ \\
\hline A lot/ little & 57 & 56 & 50 & 51 & 52 & 45 & - & - \\
\hline \multicolumn{9}{|l|}{ Talk } \\
\hline A lot & 48 & 40 & 35 & 50 & 42 & 36 & SvI $p<0.05$ & Sv1 $p<0.01$ \\
\hline A lot/ little & 84 & 71 & 75 & 84 & 81 & 79 & $\begin{array}{l}\text { SvI } p<0.05 \\
\text { SvB } p<0.05\end{array}$ & - \\
\hline \multicolumn{9}{|l|}{ Much say } \\
\hline Most say & 8 & 4 & 6 & 5 & 1 & 3 & - & - \\
\hline Most/ some & 62 & 49 & 54 & 73 & 58 & 56 & SvB $p<0.13$ & $\begin{array}{l}\text { SvI } p<0.01 \\
\text { SvB } p<0.01\end{array}$ \\
\hline
\end{tabular}


Table VI Casual Clothes - Disagreements and Resolution

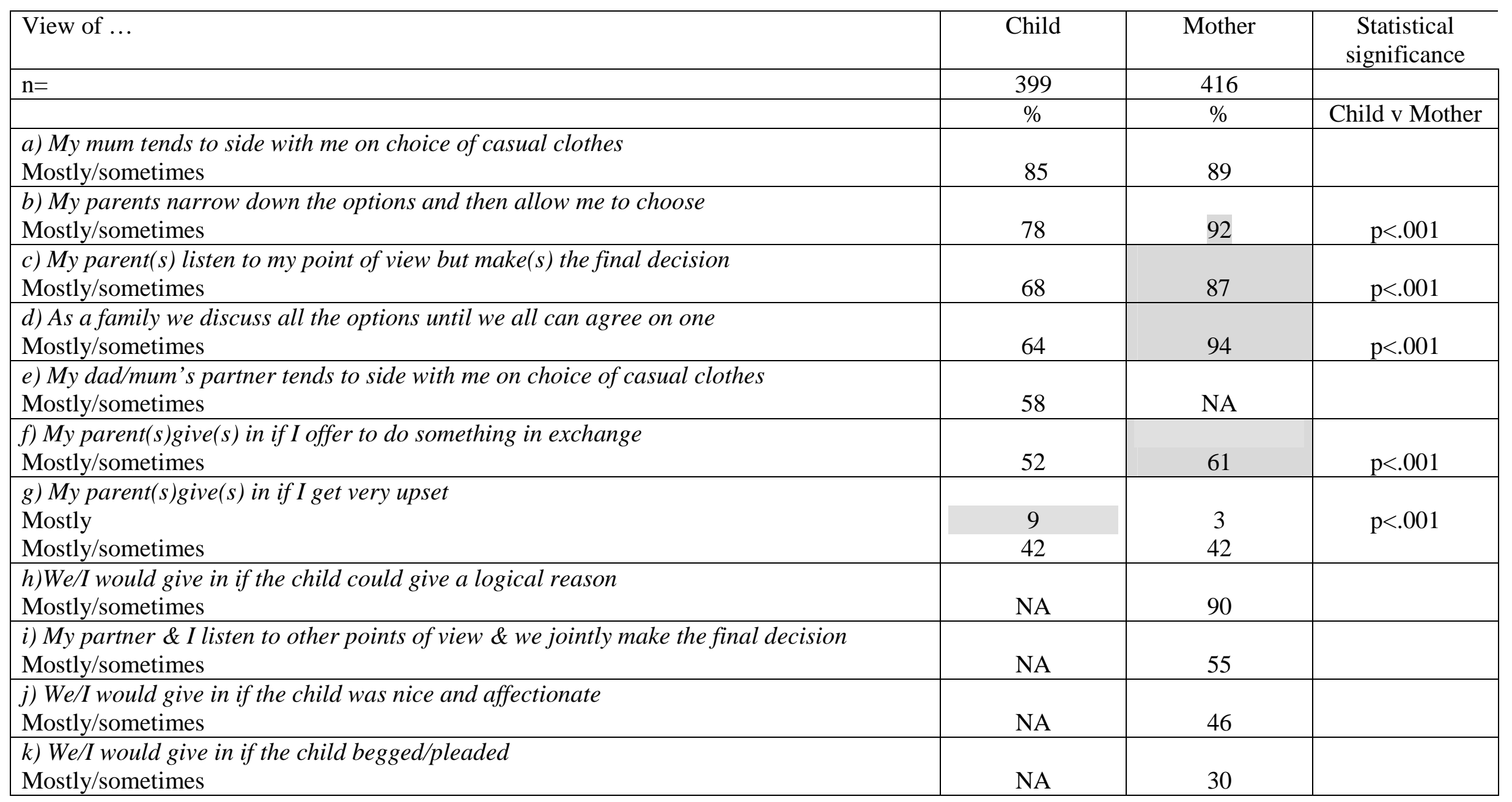


Table VII Different Types of Decision Making Strategies \& Families (Casual Clothes)

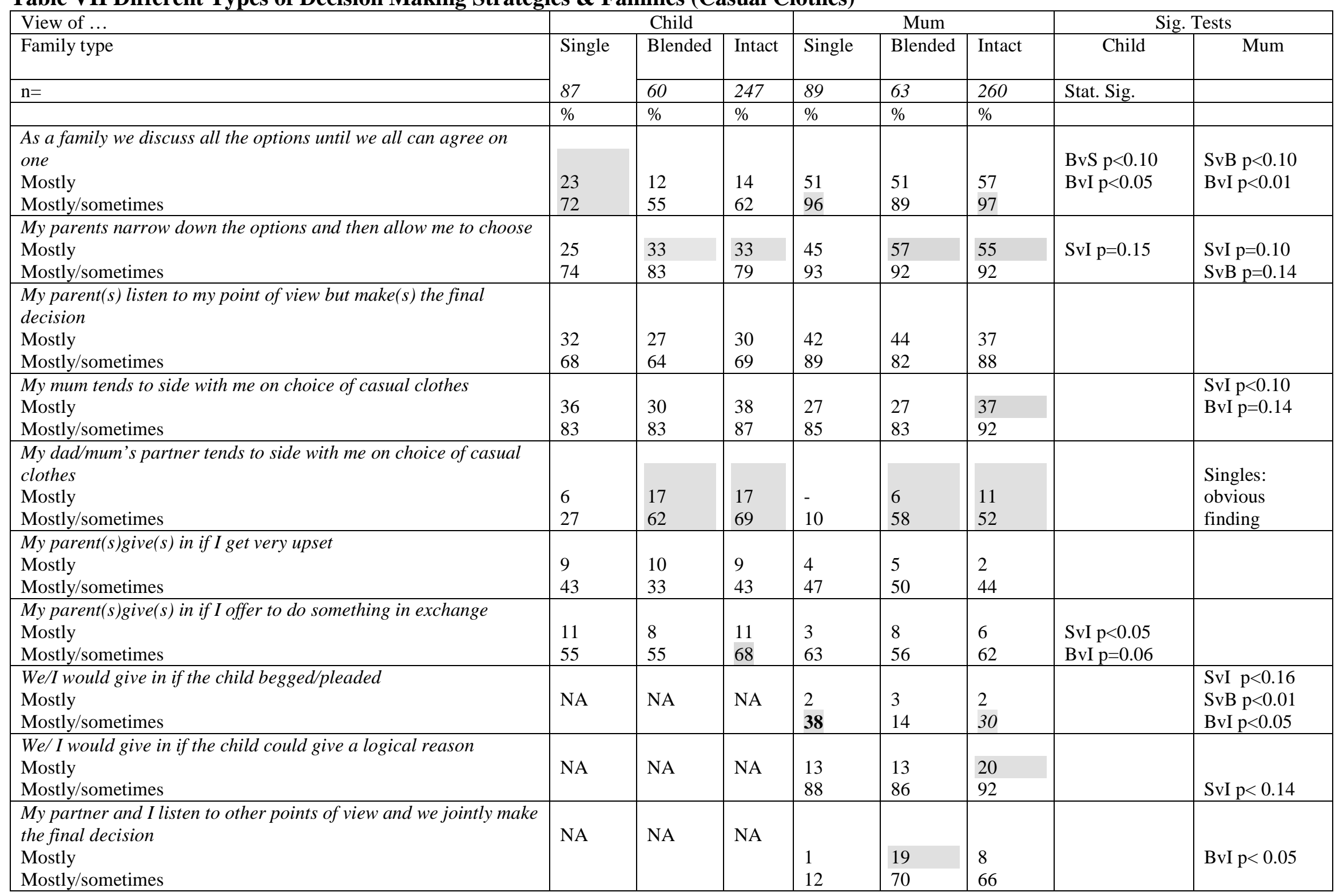


Table VIII Examining the Different Strategies for Resolving Disagreement over Family Summer Holiday Decisions

\begin{tabular}{|l|c|c|c|c|c|c|c|c|}
\hline View of..... & $\begin{array}{c}\text { TOTAL } \\
\text { Child }\end{array}$ & $\begin{array}{c}\text { TOTAL } \\
\text { Mum }\end{array}$ & $\begin{array}{c}\text { Child } \\
\text { Single }\end{array}$ & $\begin{array}{c}\text { Child } \\
\text { Blend }\end{array}$ & $\begin{array}{c}\text { Child } \\
\text { Intact }\end{array}$ & $\begin{array}{c}\text { Mum } \\
\text { Single }\end{array}$ & $\begin{array}{c}\text { Mum } \\
\text { Blend }\end{array}$ & $\begin{array}{c}\text { Mum } \\
\text { Intact }\end{array}$ \\
\hline $\begin{array}{l}\text { Base: Claiming } \\
\text { some degree of } \\
\text { upset/ } \\
\text { disagreement }\end{array}$ & 314 & 283 & 69 & 47 & 196 & 65 & 35 & 180 \\
\hline & $\%$ & $\%$ & $\%$ & $\%$ & $\%$ & $\%$ & $\%$ & $\%$ \\
\hline $\begin{array}{l}\text { Parents listen to } \\
\text { my point of view } \\
\text { then they choose }\end{array}$ & 44 & $\mathbf{6 4 * * *}$ & $41^{*}$ & $\mathbf{6 2}$ & $40 * *$ & $45^{*}$ & $\mathbf{6 7}$ & $\mathbf{7 2}$ \\
\hline $\begin{array}{l}\text { Discuss until all } \\
\text { agree }\end{array}$ & $\mathbf{4 2 * * *}$ & 29 & $\mathbf{4 5 *}$ & 26 & $45 *$ & $\mathbf{4 2 *}$ & 29 & 25 \\
\hline $\begin{array}{l}\text { Options narrowed } \\
\text { and child then } \\
\text { chooses }\end{array}$ & 6 & 6 & 9 & 4 & 6 & 8 & 6 & 1 \\
\hline
\end{tabular}

